\title{
Trypanocidal Activity of Meliaceae and Rutaceae Plant Extracts
}

\author{
Alessandra Regina Pepe Ambrozin, Paulo Cezar Vieira/ ${ }^{+}$, João Batista Fernandes, \\ Maria Fátima das Graças Fernandes da Silva, Sérgio de Albuquerque*
}

\author{
Departamento de Química, Universidade Federal de São Carlos, Rod. Washington Luiz km 235, Caixa Postal 676, 13565-905 \\ São Carlos, SP, Brasil *Departamento de Análises Clínicas, Toxicológicas e Bromatológicas, Faculdade de Ciências Farmacêuticas \\ de Ribeirão Preto, Universidade de São Paulo, Ribeirão Preto, SP, Brasil
}

The in vitro trypanocidal activity of 22 extracts and 43 fractions of plants belonging to the families Meliaceae and Rutaceae was evaluated. The extracts from leaves of Conchocarphus heterophyllus and branches of Trichilia ramalhoi were the most active. The trypanocidal activity seems to be increased by fractionation of the extracts. Fractions from C. heterophyllus and Galipea carinata were the most active and a 100\% lysis of the parasites was observed for five fractions. From one of them were isolated two flavonoids: flavone and 7-methoxyflavone, which showed weak trypanocidal activity. The results obtained from the extracts and fractions revealed that the order Rutales is a promising source for the search of new drugs for Chagas disease. Phytochemical studies with the other active fractions are underway in order to isolate compounds, which could be associated with observed activities.

Key words: Meliaceae - Rutaceae - Chagas disease - trypanocidal activity

Chagas disease (American trypanosomiasis) is caused by the flagellate protozoan Trypanosoma cruzi (Kinetoplastida, Trypanosomatina), and affects more than 18 million people in Latin America, leading to approximately 400,000 deaths per year (WHO 1997). Its treatment is still a challenge, since the only drug commercially available (benznidazole) possesses severe side effects and its activity is limited to the acute phase of the disease (De Castro 1993, Fairlamb 1999). Coura and De Castro (2002) mention that an effective chemotherapy is needed for the people who are already infected. The demonstration of parasites in chronic patients reinforces the need of finding more efficient and less toxic drugs.

In the context of efforts to improve the therapy of Chagas disease, higher plants are a potential source of new drugs, with high activity and low toxicity (Phillipson \& Wright 1991). Sepúlveda-Boza and Cassels (1996) mentioned a broad spectrum of chemical classes of substances showing activity against the parasite. Other promising compounds are the 2-aryl and 2-alkylquinoline alkaloids isolated from the extracts of the stem bark, root bark and leaves of Galipea longiflora (Rutaceae) (Fournet et al. 1994) and lignans from Zanthoxylum naranjillo (Rutaceae) (Bastos et al. 1999). In addition, we have been studying species of the order Rutales (Rutaceae, Meliaceae, Simaroubaceae, Burseraceae, and Cneoraceae) and several active substances have been isolated, mainly trypanocidal compounds (Mafezoli et al. 2000, Tomazela et al. 2000, Vieira et al. 2001).

Financial support: Fundação de Amparo à Pesquisa do Estado de São Paulo

${ }^{+}$Corresponding author. Fax.: +55-16-260.8350.

E-mail: paulo@dq.ufscar.br

Received 5 September 2003

Accepted 12 January 2004
In this paper, we present the results of the trypanocidal activity of some extracts and fractions of Almeidea coerulea, Almeidea rubra, Conchocarpus heterophyllus, and Galipea carinata (from Rutaceae family), as well as Trichilia ramalhoi (from the family Meliaceae). Also, the results of the in vitro trypomastigote bioassay with flavone (1) and 7-methoxyflavone (2), the major compounds of one active fraction, are described.

\section{MATERIALS AND METHODS}

Plant material - All screened plants were collected in Southeastern Brazil, and identified by Dr José R Pirani from the Department of Botany, University of São Paulo, Brazil. The voucher herbarium specimens were deposited at the Herbarium of that Department (Table I).

Preparation of crude extracts - Selected parts of the plants (leaves, stems, and/or branches) were dried carefully by forced air at $40^{\circ} \mathrm{C}$ and reduced to powder, followed by extraction three times with hexane by maceration at room temperature for $72 \mathrm{~h}$. After the evaporation of the solvent under reduced pressure, crude hexane extracts were obtained. This process was repeated with methanol. The hexane and methanol extracts so obtained were assayed against $T$. cruzi.

Fractionation of crude extracts - Methanol extracts of T. ramalhoi were fractionated through liquid-liquid partition with hexane-methanol-water, dichloromethanemethanol-water, ethyl acetate-methanol-water, and butanol-methanol-water. The crude extracts of A. coerulea, A. rubra, C. heterophyllus, G. carinata, and the hexane extract of the leaves of $T$. ramalhoi were submitted to vacuum liquid chromatography over silica gel using a gradient hexane, dichloromethane, ethyl acetate, and methanol, to yield the corresponding fractions, which were subsequently tested for their tryponocidal activity.

Isolation of flavone and 7-methoxyflavone - The ethyl acetate fraction of the hexane extract from the leaves of $C$. heterophyllus (AHFHA) (7.3 g) was chromatographed on a Florisil column $(8 \times 5.9 \mathrm{~cm})$ and eluted with solvents of 
TABLE I

Botanical identification of plants assayed

\begin{tabular}{llcc}
\hline Plant family & Botanical name & Collected in & Voucher number \\
\hline Rutaceae & Almeidea coerulea A. St.-Hil. & $06 / 02 / 93$ & Pirani \& Kallunki 2747 \\
& Almeidea rubra A. St.-Hil. & $19 / 05 / 00$ & Pirani et al. 4746 \\
& Conchocarpus heterophyllus (A. St.-Hil.) & $28 / 01 / 93$ & Pirani \& Kallunki 2693 \\
& Kallunki \& Pirani & $18 / 01 / 93$ & Kallunki \& Pirani 336 \\
& Galipea carinata Pirani (sp. nov.) & $18 / 05 / 00$ & Pirani et al. 4722 \\
Meliaceae & Galipea carinata Pirani (sp. nov.) & $15 / 01 / 85$ & Pirani \& Kallunki 2632 \\
\hline
\end{tabular}

increasing polarity (hexane $\rightarrow$ methanol) to afford 6 fractions. The third fraction $(1.6 \mathrm{~g})$ was rechromatographed on a Silica gel column (230-400 mesh, $3.9 \times 25.2 \mathrm{~cm})$ using hexane-EtOAc mixtures. Eight fractions were obtained. The seventh one $(1.27 \mathrm{~g})$ was identificated as flavone (1) by comparison of the ${ }^{13} \mathrm{C}$ NMR data with the literature (Kingsburry \& Looker 1975). Further purification of fraction 4 (3.12 g) performed on a Silica gel column (230-400 mesh, 3.9 x $25.2 \mathrm{~cm} ; \mathrm{CH}_{2} \mathrm{Cl}_{2} \rightarrow \mathrm{MeOH}$ ) followed by gel filtration on Sephadex LH-20 (3.2 x $49.2 \mathrm{~cm}$; MeOH) led to the isolation of 7-methoxyflavone (2) (22.7 mg) (Kingsburry \& Looker 1975). These compounds were assayed against $T$. cruzi.

Trypanocidal activity in vitro - The bioassays were carried out using blood of infected Swiss albino mice, which was collected by cardiac puncture at the peak of parasitemic infection ( 7 th day of infection for $\mathrm{Y}$ strain of
T. cruzi). The infected blood was diluted with healthy mice blood to achieve a concentration of $2.10^{6}$ forms $/ \mathrm{ml}$. Stock solutions of the extracts/fractions/compounds were prepared by dissolving in dimethylsulfoxide (DMSO). The activity of crude extracts was evaluated at $4 \mathrm{mg} / \mathrm{ml}$, fractions at $2 \mathrm{mg} / \mathrm{ml}$, pure substances at 500, 250, and $100 \mu \mathrm{g} /$ $\mathrm{ml}$. The bioassays were performed in triplicate on titration microplates (96 wells) which contained $400 \mu \mathrm{l}$ of mixture/ well. The plates were incubated at $4^{\circ} \mathrm{C}$, and the number of parasites counted after $24 \mathrm{~h}$, following the method described by Brener (1962). Infected blood with the same volume of DMSO was used as control, and gentian violet to a concentration of $250 \mu \mathrm{g} / \mathrm{ml}$ was used as positive control. The activity is expressed as percent reduction of the parasite number (lysis) and $\mathrm{IC}_{50}(\mathrm{mg} / \mathrm{ml})$ for flavone and 7-methoxyflavone were calculated using the program GraphPad Prims v.3.0.

TABLE II

Trypanocidal activity of the crude extracts Meliaceae and Rutaceae species

\begin{tabular}{|c|c|c|c|c|}
\hline Species & Plant part & Extraction solvent & Crude extract & Lysis $\%$ \\
\hline Almeidea coerulea & Branch & $\begin{array}{l}\text { Hexane } \\
\text { Methanol }\end{array}$ & $\begin{array}{l}\text { AGH } \\
\text { AGM }\end{array}$ & $\begin{array}{l}29.91 \\
55.11\end{array}$ \\
\hline Almeidea rubra & $\begin{array}{l}\text { Leaf } \\
\text { Stem }\end{array}$ & $\begin{array}{l}\text { Hexane } \\
\text { Methanol } \\
\text { Hexane } \\
\text { Methanol }\end{array}$ & $\begin{array}{l}\text { ALFH } \\
\text { ALFM } \\
\text { ALCH } \\
\text { ALCM }\end{array}$ & $\begin{array}{l}35.43 \\
54.33 \\
40.94 \\
55.90\end{array}$ \\
\hline Conchocarpus heterophyllus & $\begin{array}{l}\text { Leaf } \\
\text { Stem }\end{array}$ & $\begin{array}{l}\text { Hexane } \\
\text { Methanol } \\
\text { Hexane } \\
\text { Methanol }\end{array}$ & $\begin{array}{l}\text { AHFH } \\
\text { AHFM } \\
\text { AHCH } \\
\text { AHCM }\end{array}$ & $\begin{array}{l}99.22 \\
59.44 \\
71.65 \\
68.89\end{array}$ \\
\hline Galipea carinata $^{a}$ & $\begin{array}{l}\text { Leaf } \\
\text { Stem }\end{array}$ & $\begin{array}{l}\text { Hexane } \\
\text { Methanol } \\
\text { Hexane } \\
\text { Methanol }\end{array}$ & $\begin{array}{l}\text { GFH } \\
\text { GFM } \\
\text { GCH } \\
\text { GCM }\end{array}$ & $\begin{array}{l}61.42 \\
64.56 \\
51.97 \\
44.09\end{array}$ \\
\hline Galipea carinata & $\begin{array}{l}\text { Leaf } \\
\text { Stem }\end{array}$ & $\begin{array}{l}\text { Hexane } \\
\text { Methanol } \\
\text { Hexane } \\
\text { Methanol }\end{array}$ & $\begin{array}{l}\text { GCFH } \\
\text { GCFM } \\
\text { GCCH } \\
\text { GCCM }\end{array}$ & $\begin{array}{l}54.33 \\
20.47 \\
50.00 \\
62.99\end{array}$ \\
\hline Trichilia ramalhoi & $\begin{array}{l}\text { Leaf } \\
\text { Branch }\end{array}$ & $\begin{array}{l}\text { Hexane } \\
\text { Methanol } \\
\text { Hexane } \\
\text { Methanol }\end{array}$ & $\begin{array}{c}\text { TRFH } \\
\text { TRFM } \\
\text { TRGH } \\
\text { TRGM }\end{array}$ & $\begin{array}{l}59.44 \\
47.63 \\
84.25 \\
81.89\end{array}$ \\
\hline
\end{tabular}

a: G. carinata specimen collected in $18 / 01 / 93$ 


\section{RESULTS AND DISCUSSION}

In the present study, the trypanocidal activity of 22 extracts and 43 fractions of plants of Meliaceae and Rutaceae family was evaluated. Table II summarizes the results obtained from the crude extracts. Sixteen extracts showed significant activity (lysis $\% \geq 50$ ). The extracts from the leaves of $C$. heterophyllus (AHFH) and from the branches of T. ramalhoi (TRGH, TRGM) were the most active ones. Also the results obtained from the extracts (Table II) revealed that these species are rich sources of trypanocidal compounds, therefore the order Rutales is a promising source of new drugs for Chagas disease. The species A. coerulea and C. heterophyllus had already been tested by Mafezoli et al. (2000), however different parts of the plants were investigated.

Table III shows the results obtained from the in vitro assay of fractions against the trypomastigote form of $T$. cruzi. Trypanocidal activity seems to be enriched by fractionation of the extracts. Only fractions of $T$. ramalhoi showed a lower percentage of lysis than those of the ex-

TABLE III

Trypanocidal activity of fractions of Meliaceae and Rutaceae species

\begin{tabular}{|c|c|c|c|c|}
\hline Species & Crude extract & Vacuum liquid chromatography & Fraction & Lysis \% \\
\hline Almeidea coerulea & AGM & $\begin{array}{l}\text { Dichloromethane } \\
\text { Ethyl acetate } \\
\text { Methanol }\end{array}$ & $\begin{array}{l}\text { AGMD } \\
\text { AGMA } \\
\text { AGMM }\end{array}$ & $\begin{array}{r}100 \\
68.6 \\
12.9\end{array}$ \\
\hline Almeidea rubra & $\begin{array}{l}\text { ALFM } \\
\text { ALCM }\end{array}$ & $\begin{array}{l}\text { Dichloromethane } \\
\text { Ethyl acetate } \\
\text { Methanol } \\
\text { Dichloromethane } \\
\text { Ethyl acetate } \\
\text { Methanol }\end{array}$ & $\begin{array}{l}\text { ALFMD } \\
\text { ALFMA } \\
\text { ALFMM } \\
\text { ALCMD } \\
\text { ALCMA } \\
\text { ALCMM }\end{array}$ & $\begin{array}{l}41.4 \\
62.9 \\
40.0 \\
65.7 \\
80.0 \\
17.1\end{array}$ \\
\hline Conchocarpus heterophyllus & $\begin{array}{l}\text { AHFH } \\
\text { AHFM } \\
\text { AHCM }\end{array}$ & $\begin{array}{l}\text { Hexane } \\
\text { Dichloromethane } \\
\text { Ethyl acetate } \\
\text { Methanol } \\
\text { Hexane } \\
\text { Dichloromethane } \\
\text { Ethyl acetate } \\
\text { Methanol } \\
\text { Ethyl acetate } \\
\text { Methanol }\end{array}$ & $\begin{array}{l}\text { AHFHH } \\
\text { AHFHD } \\
\text { AHFHA } \\
\text { AHFHM } \\
\text { AHFMH } \\
\text { AHFMD } \\
\text { AHFMA } \\
\text { AHFMM } \\
\text { AHCMA } \\
\text { AHCMM }\end{array}$ & $\begin{array}{c}25.7 \\
45.0 \\
100 \\
7.1 \\
97.1 \\
25.6 \\
56.4 \\
98.6 \\
100 \\
37.0\end{array}$ \\
\hline Galipea carinata $^{a}$ & GFM & $\begin{array}{l}\text { Dichloromethane } \\
\text { Ethyl acetate } \\
\text { Methanol }\end{array}$ & $\begin{array}{l}\text { GFMD } \\
\text { GFMA } \\
\text { GFMM }\end{array}$ & $\begin{array}{l}82.6 \\
96.4 \\
50.0\end{array}$ \\
\hline Galipea carinata & $\begin{array}{l}\text { GCFH } \\
\text { GCCM }\end{array}$ & $\begin{array}{l}\text { Hexane } \\
\text { Dichloromethane } \\
\text { Ethyl acetate } \\
\text { Methanol } \\
\text { Dichloromethane } \\
\text { Ethyl acetate } \\
\text { Methanol }\end{array}$ & $\begin{array}{l}\text { GCFHH } \\
\text { GCFHD } \\
\text { GCFHA } \\
\text { GCFHM } \\
\text { GCCMD } \\
\text { GCCMA } \\
\text { GCCMM }\end{array}$ & $\begin{array}{c}100 \\
9.3 \\
11.3 \\
65.6 \\
100 \\
44.4 \\
31.1\end{array}$ \\
\hline Trichilia ramalhoi & $\begin{array}{l}\text { TRFH } \\
\text { TRFM }\end{array}$ & $\begin{array}{l}\text { Hexane } \\
\text { Dichloromethane } \\
\text { Ethyl acetate } \\
\text { Methanol } \\
\text { Liquid-liquid partition } \\
\text { Hexane } \\
\text { Dichloromethane } \\
\text { Ethyl acetate } \\
\text { Methanol } \\
\text { Butanol } \\
\text { Liquid-liquid partition } \\
\text { Hexane } \\
\text { Dichloromethane } \\
\text { Ethyl acetate } \\
\text { Methanol } \\
\text { Butanol }\end{array}$ & $\begin{array}{l}\text { TRFHH } \\
\text { TRFHD } \\
\text { TRFHA } \\
\text { TRFHM } \\
\text { TRFMH } \\
\text { TRFMD } \\
\text { TRFMA } \\
\text { TRFMM } \\
\text { TRFMB } \\
\text { TRGMH } \\
\text { TRGMD } \\
\text { TRGMA } \\
\text { TRGMM } \\
\text { TRGMB }\end{array}$ & $\begin{array}{r}49.7 \\
8.6 \\
28.5 \\
15.2 \\
\\
12.6 \\
25.8 \\
21.9 \\
31.1 \\
29.8 \\
\\
68.2 \\
76.2 \\
13.9 \\
23.2 \\
12.6\end{array}$ \\
\hline
\end{tabular}

a: G. carinata specimen collected in 18/01/93 
TABLE IV

Trypanocidal activity of flavone (1) and 7-methoxyflavone (2) isolated from Conchocarpus heterophyllus

\begin{tabular}{lcccc}
\hline Compound & \multicolumn{3}{c}{ Concentration $(\mu \mathrm{g} / \mathrm{ml})$ x Lysis \% $( \pm$ S.D. $)$} & $\mathrm{IC}_{50}(\mu \mathrm{g} / \mathrm{ml})$ \\
\cline { 2 - 3 } & 100 & 250 & 500 \\
\hline
\end{tabular}

(1)<smiles>O=c1cc(-c2ccccc2)oc2ccccc12</smiles>

$34.5 \pm 10.9$

$12.1 \pm 7.4$
$38.6 \pm 8.1$

$48.6 \pm 6.4$

2116.0

(2)<smiles>CCCCCOc1ccc2c(=O)cc(-c3ccccc3)oc2c1</smiles>

$31.8 \pm 3.1$
$38.6 \pm 8.1$

787.1

S.D.: standard deviation

tracts. Ten fractions exhibited lysis above $80 \%$, among them: the dichloromethane fraction from the methanolic extract of A. coerulea, AGMD (100\%); the ethyl acetate fraction from the methanolic extract of the stem of $A$. rubra, ALCMA (80\%); the ethyl acetate fraction from the hexane extract and the hexane and methanol fractions from the methanolic extract of the leaves and the ethyl acetate fraction from the methanolic stem extract of $C$. heterophyllus -AHFHA(100\%), AHFMH (97.1\%), AHFMM (98.6\%), and AHCMA (100\%); the dichloromethane and ethyl acetate fractions from the methanolic extract and the hexane fraction from the hexane extract of leaves of $G$. carinata GFMD (82.6\%), GFMA (96.4\%), GCFHH (100\%) as well as the dichloromethane fraction from the methanolic extract of the stem of the same plant - GCCMD (100\%). It will be noted that the best results were obtained from Conchocarpus and Galipea fractions. Phytochemical studies of all active fractions are underway in order to isolate the compounds which could be associated with observed activities.

One active fraction from $C$. heterophyllus (AHFHA) was investigated leading to the isolation of flavone (1) and 7-methoxyflavone (2), which were assayed against $T$. cruzi (Table IV). The results showed that these compounds have weak trypanocidal activity, particularly when compared to other flavonoids isolated from Trixis vauthieri (Ribeiro et al. 1997). The trypanocidal effect of the fraction AHFHA may be due to a combination effect between flavone and 7-methoxyflavone, which are the major compounds in this fraction. This possibility will be assessed by new bioassays with mixtures of these substances, which exist in the same proportion in the plant.

It is possible that the activity of the Rutaceae may be associated with coumarins and alkaloids (derived from anthranilic acid), which are characteristic of this family (Gray 1983, Mester 1983). C-glucosyl flavones (Jay et al. 1979, Wirasutisna et al. 1986), 2-quinolone and other alkaloids (Moulis et al. 1983), cycloartane triterpenoids and further alkaloids (Santos et al. 1998) have already been isolated from Almeidea. Galipea has afforded a hydro- xychalcone (López et al. 1998), a chromone (López et al. 1997), a coumarin (Wirasutisna et al. 1987), O- and Cglycosylflavones (Bakhtiar et al. 1990, 1994), and several 2-quinoline alkaloids (Fournet et al. 1989, 1993, Vieira \& Kubo 1990, Rakotoson et al. 1998, Jacquemond-Collet et al. 1999). The structural diversity of metabolites from Rutaceae and the trypanocidal activity of 2-quinoline alkaloids and the lignan methylpluviatolide isolated from $G$. longiflora and Z. naranjillo (Fournet et al. 1994, Bastos et al. 1999) stimulated us to choose these plants. The trypanocidal activities observed confirm the previously noted potential of plants of the Rutaceae.

T. ramalhoi was the only Meliaceae species tested and no previous work on this plant was found. Meliaceae are a rich source of limonoids, however it seems that this class of compounds has never been evaluated for trypanocidal activity before (Champagne et al. 1992).

Finally, the results obtained in this study confirm the order Rutales as a fruitful source of new antichagasic compounds, since in the present work 16 active extracts and several fractions have been obtained, 5 of them showing $100 \%$ reduction of the parasite number. The more promising species seem to be $C$. heterophyllus and $G$. carinata although the weakly trypanocidal flavone (1) and 7methoxyflavone (2) in their isolated form do not reproduce the activity of the crude extract. The full explanation of the observed activity of these fractions must await the results of the ongoing phytochemical studies.

\section{ACKNOWLEDGEMENTS}

To Dr José Rubens Pirani for collecting and identificating all the mentioned plants.

\section{REFERENCES}

Bakhtiar A, Gleye J, Moulis C, Fouraste I, Stanislas E 1990. CGlycosylflavones from Galipea trifoliata. Phytochemistry 29: 1339-1340.

Bakhtiar A, Gleye J, Moulis C, Fouraste I 1994. O-GlycosylC-glycosylflavones from Galipea trifoliata. Phytochemistry 35: 1593-1594.

Bastos JK, Albuquerque S, Silva MLA 1999. Evaluation of the 
trypanocidal activity of lignans isolated from the leaves of Zanthoxylum naranjillo. Planta Med 65: 541-544.

Brener Z 1962. Therapeutic activity and criterion of cure on mice experimentally infected with Trypanosoma cruzi. Rev Inst Med Trop São Paulo 4: 389-396.

Champagne DE, Koul O, Isman MB, Scudder GGE, Towers GHN 1992. Biological activity of limonoids from the Rutales. Phytochemistry 31: 377-394.

Coura JR, De Castro SL 2002. A critical review on Chagas disease chemotherapy. Mem Inst Oswaldo Cruz 97: 3-24.

De Castro SL 1993. The challenge of Chagas' disease chemotherapy: an update of drugs assayed against Trypanosoma cruzi. Acta Trop 53: 83-98.

Fairlamb AH 1999. Future prospects for the chemotherapy of Chagas disease. Medicina (B Aires) 59: 179-187.

Fournet A, Barrios AA, Munoz, V, Hocquemiller R, Roblot F, Cavé A, Richomme P, Bruneton J 1994. Antiprotozoal activity of quinoline alkaloids isolated from Galipea longiflora, a Bolivian plant used as a treatment for cutaneous leishmaniasis. Phytother Res 8: 174-178.

Fournet A, Hocquemiller R, Roblot F, Cavé A, Richomme P, Bruneton J 1993. Les chimanines, nouvelles quinoleines substituées en 2, isolées d'une plante bolivienne antiparasitaire: Galipea longiflora. J Nat Prod 56: 1547-1552.

Fournet A, Vagneur B, Richomme P, Bruneton J 1989. Aryl-2 et alkyl-2 quinoléines nouvelles isolées d'une Rutacée bolivienne: Galipea longiflora. Can J Chem 67: 2116-2118.

Gray AI 1983. Structural diversity and distribution of coumarins and chromones in the Rutales. In PG Waterman, Grundon MF (eds), Chemistry and Chemical Taxonomy of the Rutales, Academic Press, London, p. 97-146.

Jacquemond-Collet I, Hannedouche S, Fabre N, Fourasté I, Moulis C 1999. Two tetrahydroquinoline alkaloids from Galipea officinalis. Phytochemistry 51: 1167-1169.

Jay M, Gleye J, Bouillant ML, Stanislas E, Moretti C 1979. Nouvelles C-arabinosyl flavones extraites de Almeidea guianensis (Rutaceae). Phytochemistry 18: 184-185.

Kingsburry CA, Looker JH 1975. Carbon-13 spectra of methoxyflavones. J Org Chem 40: 1120-1124.

López JA, Barillas W, Gomes-Laurito J, Martin GE, Al-Rehaily AJ, Zematis MA, SchiffJr PL 1997. Granulosin: a new chromone from Galipea granulosa. J Nat Prod 60: 24-26.

López JA, Barillas W, Gomes-Laurito J, Martin GE, Lin F, AlRehaily AJ, Zematis MA, Schiff Jr PL 1998. Galiposin: a new $\beta$-hydroxychalcone from Galipea granulosa. Planta
Med 64: 76-77.

Mafezoli J, Vieira PC, Fernandes JB, Da Silva MFGF, Albuquerque $S$ 2000. In vitro activity of Rutaceae species against the trypomastigote form of Trypanosoma cruzi. J Ethnopharmacol 73: 335-340.

Mester I 1983. Structural diversity and distribution of alkaloids in the Rutales. In PG Waterman, MF Grundon (eds), Chemistry and Chemical Taxonomy of the Rutales, Academic Press, London, p. 31-96.

Moulis C, Wirasutisna KR, Gleye J, Loiseau P, Stanislas E, Moretti C 1983. A 2-quinolone alkaloid from Almeidea guianensis. Phytochemistry 22: 2095-2096.

Phillipson JD, Wright CW 1991. Medicinal plants against protozoal diseases. Trans R Soc Trop Med Hyg 85: 155-165.

Rakotoson JH, Fabre N, Jacquemond-Collet I, Hannedouche S, Fourasté I, Moulis C 1998. Alkaloids from Galipea officinalis. Planta Med 64: 762-763.

Ribeiro A, Piló-Veloso D, Romanha AJ, Zani CL 1997. Trypanocidal flavonoids from Trixis vauthieri. J Nat Prod 60: 836-838.

Santos CS, Januário AH, Vieira PC, Fernandes JB, Da Silva MFGF, Pirani JR 1998. Cycloartane triterpenoid and alkaloids from Almeidea spp. J Braz Chem Soc 9: 39-42.

Sepúlveda-Boza S, Cassels BK 1996. Plant metabolites active against Trypanosoma cruzi. Planta Med 62: 98-105.

Tomazela DM, Pupo MT, Passador EAP, DaSilva MFGF, Vieira PC, Fernandes JB, Rodrigues-Filho E, Oliva G, Pirani JR 2000. Pyrano chalcones and a flavone from Neoraputia magnifica and their Trypanosoma cruzi glycosomal glyceraldehyde-3-phosphate dehydrogenase-inhibitory activities. Phytochemistry 55: 643-651.

Vieira PC, Kubo I 1990. Molluscicidal quinoline alkaloids from Galipea bracteata. Phytochemistry 29: 813-815.

Vieira PC, Mafezoli J, Pupo MT, Fernandes JB, Da Silva MFGF, Albuquerque S, Oliva G, Pavão F 2001. Strategies for the isolation and identification of trypanocidal compounds from the Rutales. Pure Appl Chem 73: 617-622.

WHO-World Health Organization 1997. Chagas disease. Thirteenth Programme Report UNDP/TDR, Geneve.

Wirasutisna KR, Gleye J, Moulis C, Stanislas E, Moretti C 1986. Flavone C-Glycosides of Almeidea guyanensis. Phytochemistry 25: 558-559.

Wirasutisna KR, Gleye J, Moulis C, Stanislas E, Moretti C 1987. Galipein, a coumarin from Galipea trifoliata. Phytochemistry 26: 3372. 